\title{
Product and Communication Analysis of Constituent Loyalty of Indonesian Democracy Party (PDIP) in Central Java, Indonesia
}

\author{
Hakam Ali Niazi ${ }^{1}$, Dewi Puspaningtyas Faeni ${ }^{2}$
}

\begin{abstract}
The use of marketing methods in politics is known as political marketing. In marketing politics, the emphasis is the use of approach and method of marketing mix that is called $4 P$ that is product, price, distribution (place), and promotion used to help politicians and political parties to be more efficient and effective in building two-way relationships with constituents and communities. This study aims to determine the effect simultaneously and partially the product variable (policy, figure, structure and symbolic context) and Communication variables (advertising, direct marketing, special event, person contact, public relations, merchandise, political post) to the Loyalty of PDI Constituents Struggle and know the dominant influential variable to Loyalty of PDIP as a Political Party constituency in Central Java.The type of research used in this study is explanatory research to examine the effect of independent variables of product and communication $(x)$ on the dependent variable that is customer loyalty (y). The research instrument used is questionnaire. While the sampling using random sampling technique to PDIP constituent consisting of structural and organization of PDIP. The data analysis tools used in this research are validity test, reliability test, multiple regression test, classical assumption test which includes multicollinearity test, heteroscedasticity test, normality test, correlation coefficient, dertermination coefficient and hypothesis testing covering $F$ test and $t$ test.The results of the research indicate that the Product affects Loyalty with correlation coefficient value of 0.487. The amount of influence of the Product on the formation of Loyalty is 23, 7\%, change of constituent loyalty for each increase of one unit of Product is equal to 0,584. Komunikas affects Loyalty with the value of correlation coefficient of 0.495 , the magnitude of the effect of Communication on the formation of Loyalty is 24, $5 \%$. The change of loyalty for each increase of one Communication unit is 0,622.
\end{abstract}

\section{Introduction}

\subsection{Research Background}

"Marketing mix is the set of marketing tools that the firm uses to marketing its marketing objectives in the market." (Marketing Management 1997) which more or less has a marketing mix meaning is a collection of controllable marketing variables used by a business entities to achieve

Revised Manuscript Received on July 05, 2019.

Hakam Ali Niazi,

Faculty of Economics and Business, Universitas Budi Luhur Jakarta,

hakamyanu@gmail.com marketing objectives within the target market [1-2].

According to Kotler (1997: 92), Marketing mix is the set of marketing tools that the firm uses to pursue its marketing objectives in the target market. Marketing mix is a number of marketing tools that a company uses to convince a targeted marketing object or target market [3-5].

Zeithaml and Bitner in Yazid (2001) describe promotional factors as: "The promotional factors in service marketing consist of: sales force or service, number, selection, training, incentives, targets, media types, and advertising, elements of promotion mix (advertising, sales promotion, personal selling, and publicity)".

Carl I. Hovland (in Widjaja, 2000: 26-27) defines communication as a process whereby one moves the stimulus which is usually a symbol of words to change the behavior of others. So, then that communication is a common denominator and for that purpose one must influence others first before the other person thinks, behaves and behaves the same as us [6-7].

Political marketing is a series of planned, strategic but also tactical, long-term and short-term dimensions, to propagate political meaning to voters with the aim of establishing and instilling hope, attitudes, beliefs, orientations and behavior of voters to generally support, and especially choosing the party (Nursal, 2004). According Firmanzah (2008: 203), in the process of Political Marketing, used 4Ps marketing mix application, namely: (1) Product (product) means party, candidate and party ideas that will be constituen.Produk this contains concept, ideological identity. Both past and present contribute to the formation of a political product. (2) Promotion (promotion) is an advertising, public relations and promotion effort for a party that is mixed in such a way in accordance with the needs of the community. In this case, media selection should be considered. (3) Price (Price), covering many things, from economic, psychological, to the national image. The economic price includes all costs incurred during the campaign period. Psychological price refers to the price of psychological perception for example, voters feel comfortable, with ethnic background, religion, education and others. While the price of national image is related to whether the voters feel the candidate can give a positive image and can be the pride of the country. (4) Placement is

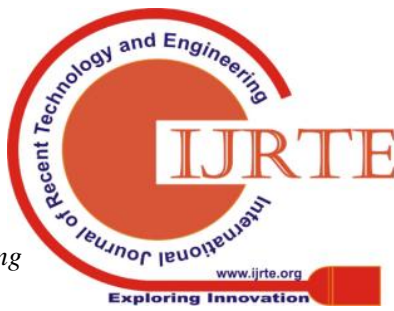


closely related to the way in which a party is present or distributed and its ability to communicate with voters. This means that a party must be able to map the structure and characteristics of both geographic and demographic communities [8-10].

Using 4Ps marketing in politics makes political marketing not only limited to advertising problems, but more comprehensive. Political marketing concerns the way a political institution or political party formulates political products, develops campaign publications and political communication programs, segmentation strategies to meet the needs of the society to the calculation of the price of a political product (Firmanzah, 2008: 211)

Marketing strategies are already time to be applied in politics, given the changes along with advances in information technology and communications. The more integrated the global community and the pressure to apply the principles of democracy, political institutions also require alternative approaches to building relationships with constituents and the wider community. It is in this context that marketing as a discipline that develops in the business world is assumed to be useful for the political institutions of marketing science usually known as a discipline that connects producers with consumers [11-14].

Relationships in marketing not only happen one direction, but two directions simultaneously. Manufacturers need to introduce and bring products and services to consumers. All marketing efforts are meant for convince consumers that the "product" that is sold does have a better quality than the products sold by competitors. The methods and approaches of marketing science can help political institutions to bring political products to constituents and methods in the preparation of political products, distribution of political products to the public and ensure that political products are more uuggul compared with competitors [1520].

Political parties are the most powerful tool for human beings to achieve their political goals. From the urgency of this political party there emerges a reply in society, "modern politicians without political parties are the same as fish out of water," Sigmund Neumann in his "Modern Political Parties" argues that political parties are organizations of political activities seeking to control power government and seize the support of the people on the basis of competition with a group or other groups who have different views [2024].

Ramlan Surbakti in his book "Understanding Political Science" states that the political party comes from three theories namely: First, the institutional theory that sees no relationship between the early parliament and the emergence of political parties. Second, the historical situation theory that sees the emergence of political parties as an attempt to overcome the crisis of political system caused by widespread societal change. Third, the development theory that sees political parties as a product of socio-economic modernization. According to him, the characteristics of political parties are rooted in local communities, conducting continuous activities, trying to gain and maintain power in government and participate in elections [25-27]. society at large. Political institutions can use marketing

Miriam Budiarjo (1978) defines a political party as an organized group whose members have the same orientation, values and ideals. The aim of this group is to gain political power and seize the political position - (usually) in a constitutional way - to implement their policies [28-29].

Disclosure of information and communication and the end of the cold war between capitalist and socialist resulted in the absence of ideological opposition in society. All the joints of people's life, nation and state have adopted a capitalism that is pragmatism, consequently the ideological struggle becomes vague. Society does not matter what form of ideology is like? The importance of society is how a party can solve and provide solutions to the problems faced by society, whether economic, social, cultural, security. Because what society sees is the ability of political parties to provide solutions to their problems, what society sees as a party work program. Although the work program is actually based on the ideology of a party. But the people only see the party's work program is not the party ideology [30-34].

In this decade there is a tendency of non-partisan numbers that is society that does not bind itself to a particular party, at this time experiencing an increasing tendency. This is one of them caused by the critical power of the community towards political parties which is preceded by the improvement of the democratization process. Non-partisan views the ability and performance of the party in overcoming all existing problems rather than just looking at the ideological side of a party. Indonesian society today is very pragmatism, which is proven in the implementation of the 2009 Election, the election system opens great opportunities for transactions in voting. The nature of pragmatism is not only done by contestants of election participants, but also by election organizers. The condition is very detrimental to the process of democratization and maturation in the life of nation and state. The waves of democratization, which further diminish the practice of authoritarian power and closed political system, make it a political party for political competition for constituents. Competition between political parties is what became a distinctive characteristic that color the world of politics today. Thus constestan elections / political parties face to face with the community / constituents to develop work programs that can attract the community [35-36].

Central Java Province is one of the provinces in Indonesia which is located quite strategically because it is in the solid land of Java Island and flanked by two large provinces of West Java and East Java and the Special Region of Yogyakarta. Administratively, the total area of Central Java Province is 32,544.12 Hectares (Ha) and consists of 29 districts and 6 cities with 565 districts and 8,568 villages [37].

In the province of Central Java, PDIP is a party that has many supporters. The magnitude of this support is evident from the results of three post-election elections, namely the 1999, 2004 and 2009 elections. In the 1999 election, the Central Java PDIP won support of 43 percent, in the 2004 election won 30 percent of the vote or $5,262,749$ total votes in the elections in 2009 from 10 dapil in Central Java, PDIP successfully gain votes in seven dapil. Two dapil are controlled by Democrats, and the rest are Golkar. 
Democratic phenomenon has not been able to destabilize the PDIP [38].

\subsection{Problem Identification}

Problem Identification In this research are:

1. How is the Program and Communication picture implemented by PDIP.

2. Whether Program and Communication variables affect the Loyalty of PDIP Constituents. Struggle.

\section{Research Methodology}

Data analysis used in this research is multiple linear regression (Multiple Regresion). Data analysis using statistics with SPSS software version 17.0. The variables to be studied and identified in this research are two:

1. Independent variable or independent variable, the variable whose value affects the value of other variables. This variable is given an $\mathrm{X}$ symbol, including:

Product (X1), and Communication (X2).

2. Dependent variable or dependent variable, that is variable whose value depends on value of other variable. This variable is given the symbol Y, in the

research of Loyalty constituent PDIP (Y)

\subsection{Data Collection Methods}

The data used in the preparation of the research is the primary data collected for analysis based on data obtained from the respondents' answers to the entire PDI Structural Struggle structure in Central Java and the Management of Community Organizations affiliated with the PDI Perjuangan in Central Java during the Period from January to June 2012.

\section{Data Analysis}

Data analysis techniques in this study by using multiple regression analysis to obtain a comprehensive picture of the relationship between variables one with another variable. In this case for the dependent variable is Loyalty of PDI Perjuangan (Y) constituent and the independent variable is Product (X1), Communication (X2). From the research model, it can be arranged mathematical model of Multiple Linear Regression Method (Multiple Linier Regression Method) as follows:

$\mathrm{Y}=\alpha+\beta 1 \mathrm{X} 1+\beta 2 \mathrm{X} 2+\mathrm{e}$
Input :

$\mathrm{Y} \quad=$ Constituent PDIP Loyalty

$\alpha=$ Constanta.

$\beta 1-\beta 3=$ Coefficient regression of independenr variables.

$\mathrm{X} 1=$ Product

$\mathrm{X} 2=$ Communication

$\mathrm{e} \quad=$ Standard deviation

\section{Results and Discussion}

The study was conducted in Central Java, with a sample of 301 respondents from the study population of 2,340 PDIP officials and CSOs affiliated to PDIP in Central Java.

Table 1 : Respondents Gender

\begin{tabular}{|l|l|l|}
\hline Male & Female & Total \\
\hline $44,52 \%$ & $55,48 \%$ & $100,00 \%$ \\
\hline
\end{tabular}

Source: Niazi, SPSS, 2017

Based on table 1: Sex of respondents can be seen that most respondents $(55.48 \%)$ of respondents are female, while (44.52\%) other respondents Men.

Table 2 : Respondents by Age

\begin{tabular}{|l|l|}
\hline Age & Precentage \\
\hline 20 th s/d 30 th & $10,30 \%$ \\
\hline 30 th s/d 40 th & $32,89 \%$ \\
\hline 40 th s/d 50 th & $34,55 \%$ \\
\hline 50 th s/d 60 th & $22,25 \%$ \\
\hline Total & $\mathbf{1 0 0 \%}$ \\
\hline
\end{tabular}

Source: Niazi, SPSS, 2017

Based on table 2: the age of respondents can be seen that most respondents $(34.55 \%)$ respondents are aged between 40 th to $50 \mathrm{th},(32.89 \%)$ respondents aged between 30 th s / d 40 years, $(22,25 \%)$ respondents aged 50 th to 60 th and $(10,30 \%)$ respondents aged 20 th s / d 30 year old.

Table 3 : Correlations

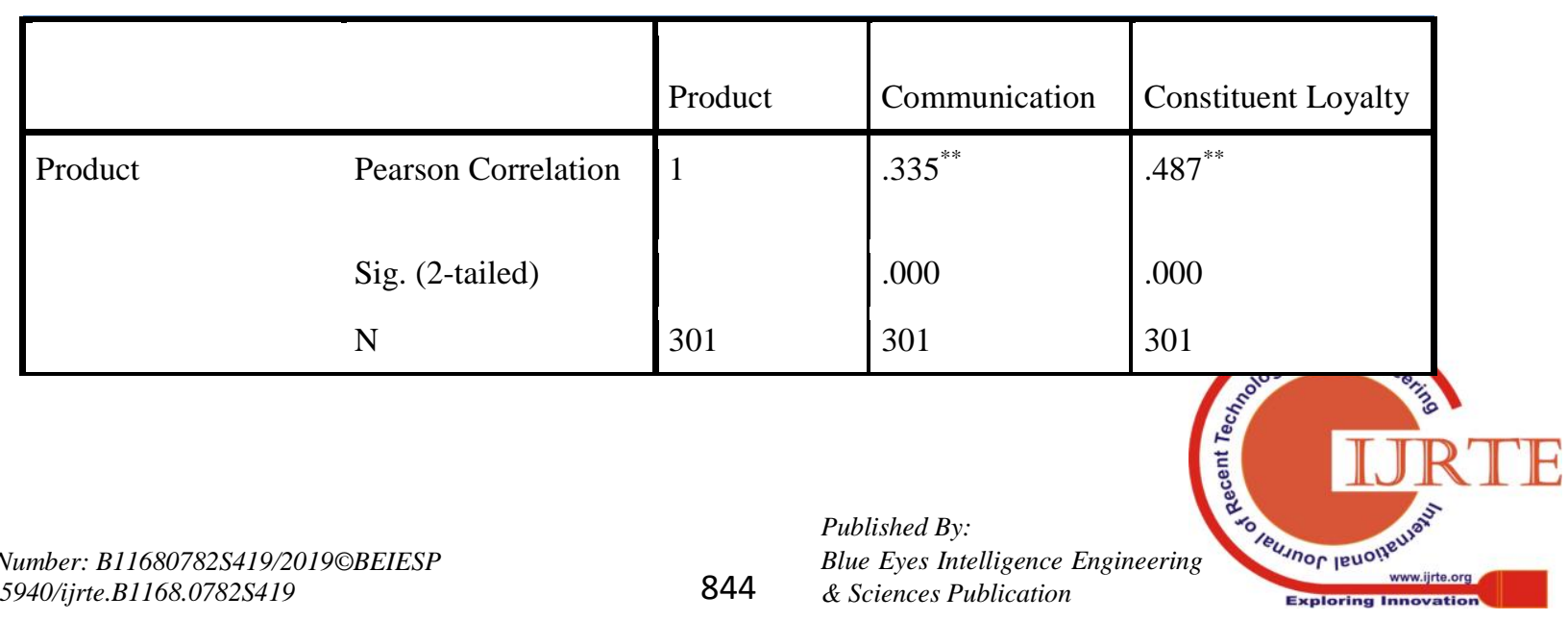


Product and Communication Analysis of Constituent Loyalty of Indonesian Democracy Party (PDIP) in Central Java, Indonesia

Table 3 : Correlations

\begin{tabular}{|ll|l|l|l|}
\hline & & Product & Communication & Constituent Loyalty \\
\hline Product & Pearson Correlation & 1 & $.335^{* *}$ & $.487^{* *}$ \\
\cline { 2 - 4 } & Sig. (2-tailed) & & .000 & .000 \\
& $\mathrm{~N}$ & 301 & 301 & 301 \\
\hline Communication & Pearson Correlation & $.335^{* *}$ & 1 & $.495^{* *}$ \\
& Sig. (2-tailed) & .000 & & .000 \\
& $\mathrm{~N}$ & 301 & 301 & 301 \\
\hline & Pearson Correlation & $.487^{* *}$ & $.495^{* *}$ & 1 \\
\hline Constituent Loyalty & & .000 & 301 \\
\hline
\end{tabular}

**. Correlation is significant at the 0.01 level (2-tailed).

Source: Niazi, SPSS, 2017

Based on table 3: Correlations, it is clear that the effect of the Product on Constituent Loyalty is 0.487 or $48.7 \%$ and Communication on Constituent Loyalty is 0.495 or $49.5 \%$ means that:
1. With correlation coefficient value equal to 0.487 which means showing correlation correlation between Product to Loyalty of Constituent (Y). While

With the value of correlation coefficient of 0.495 which means showing substantial correlation correlation with between Communication with Loyalty Constituent

Tabel 4 : Model Summary

\begin{tabular}{|l|l|l|l|l|}
\hline Model & R & R Square & Adjusted R Square & $\begin{array}{l}\text { Std. Error of the } \\
\text { Estimate }\end{array}$ \\
\hline 1 & $.601^{\mathrm{a}}$ & .361 & .357 & 4.530 \\
\hline
\end{tabular}

a. Predictors: (Constant), Product, Communication

b. Dependent Variable: Constituent Loyalty
Constituent Loyalty is $36.1 \%$ while the remaining $63.9 \%$ is influenced by other variables.

Source: Niazi, SPSS, 2017

Based on Table 4: Summaryc Model, it is clear that the effect of Product and Communication variable on

Table 5 : Coefficients ${ }^{\mathrm{a}}$

\begin{tabular}{|c|c|c|c|c|c|c|}
\hline \multirow{2}{*}{\multicolumn{2}{|c|}{ Model }} & \multicolumn{2}{|c|}{$\begin{array}{l}\text { Unstandardized } \\
\text { Coefficients }\end{array}$} & \multirow{2}{*}{\begin{tabular}{|l} 
Standardized \\
Coefficients
\end{tabular}} & \multirow[b]{2}{*}{$\mathrm{T}$} & \multirow[b]{2}{*}{ Sig. } \\
\hline & & B & Std. Error & & & \\
\hline & (Constant) & 3.458 & 2.701 & & 1.281 & .201 \\
\hline & Produk & .433 & .059 & .361 & 7.347 & .000 \\
\hline & Komunikasi & .461 & .061 & .374 & 7.610 & .000 \\
\hline
\end{tabular}


a. Dependent Variable: Loyalitas Konstituen Source: Niazi, SPSS, 2017

Based on Table 5: Coefficientsa explained about the effect of Product and communication on Constituent Loyalty. Based on table 4 then can be written the regression line as follows:

\section{YConstituent $=\mathbf{3 . 4 5 8}+\mathbf{0 . 4 3 3}$ product + 0.461communication}

The description of the above regression line is as follows:

The constant value of 3458 means that if the value is zero Communications Products and then Loyalits Constituents of 3458 .

Products coefficient value of 0433 means that if the value is zero then the constituent loyalty if products rose by 1 unit of the Loyalty constituents will rise by 0.433 and vice versa.

PDIP must increase its party products to constituents both in quantity and in quality which is expected to increase the formation of constituent loyalty. The influence of the product is still very low on loyalty for it needs to be studied and researched more deeply by PDI Perjuangan of Central Java about constituent desire to party product whether it is a party policy or regulation, party's personal structural, candidate of legislative, executive candidate and also good partying activities internal or external.

Structural consolidation, election and elections that always have an impact on constituent loyalty, therefore the process should be more attention so as not to have an impact on the decrease in constituent loyalty.

Communication coefficient value of 0.461 means if the loyalty of the constituent value is zero then if the Communication goes up by 1 unit then the loyalty of the Constituent will rise by 0.461 and vice versa. That communications built by party structures to constituents are still very low, so that many constituents still do not know what the party does that will have a positive impact on the level of constituent loyalty. Communication plays an important role to increase the party's insight, knowledge and image in society. Communication media and the intensity of party communication to constituents play an important role, both of which are less optimized, thus affecting the level of constituent loyalty.

Table 6 : ANOVA ${ }^{\mathrm{B}}$

\begin{tabular}{|l|l|l|l|l|l|}
\hline Model & Sum of Squares & Df & Mean Square & F & Sig. \\
\hline 1 & Regression & 3453.338 & 2 & 1726.669 & 84.158 \\
& Residual & 6114.090 & 298 & $.000^{\mathrm{a}}$ \\
& Total & 9567.429 & 300 & 20.517 \\
\end{tabular}

a. Predictors: (Constant), product, communication

1. B. Dependent Variable: constituent loyalty

Source : Niazi, SPSS, 2017

Based on table 6: ANOVAB Hypothesis Testing Simultaneously (Test F). This test is conducted to determine whether the independent variables together influence significantly / not to the dependent variable.

If Fhitung < Ftabel (n-k-1) then Ho accepted and Ha rejected

If Fcount $>$ Ftable (n-k-1) then $\mathrm{Ho}$ is rejected and $\mathrm{Ha}$ accepted

Means together variables X1, X2 affect the variable Y.

Hypothesis:

Ho $=\mathrm{b} 1=\mathrm{b} 2=0$ (Brand Personality Aspect, Sales Promotion has no effect on Brand Equity)

$\mathrm{Ha}=\mathrm{b} 1=\mathrm{b} 2 \neq 0$ (Brand Personality Aspect, Sales Promotion Influence on Brand Equity)

Result:

Fhount $=0.00$

Ftabel $(\mathrm{n}-\mathrm{k}-1)=(300-2-1)$ obtained 3.00
The significance value of $\mathrm{F}$ test obtained significance value $<3.00(0.00<3.00)$, then Ho is rejected which means Ha accepted where. Product and Communication Aspects Affect Constituent Loyalty.

Based on table 5: Coefficients Partial Hypothesis Testing (Test $\mathrm{t}$ ) This test is conducted to determine whether the independent variables partially significant effect on the dependent variable.

Hypothesis:

Ho: $\beta 1=0$ (Product Aspect has no effect on Constituent Loyalty)

Ha: $\beta 1 \neq 0$ (Product Aspects affect Loyalty

Constituents)

$\mathrm{Ho}^{1}: \quad \beta 2=0$ (Aspects of Communication affect Loyalty 


\section{Constituents)}

$\mathrm{Ha}^{1}$ : $\beta 2 \neq 0$ (Communication Aspects of Constituent Loyalty)

If the probability of tcount and ttable is smaller at alpha 0.05 then the null hypothesis (Ho) is rejected and the alternative hypothesis (Ha) is accepted

If the probability of tcount and ttable is smaller at alpha 0.05 then the null hypothesis ${ }^{1}\left(\mathrm{Ho}^{1}\right)$ is rejected and the alternative hypothesis ${ }^{1}\left(\mathrm{Ha}^{1}\right)$ is accepted.

Result:

1. Variable Coefficient Testing "Product" ( $\beta 1)$

2. $\mathrm{T}$ arithmetic was obtained 7,347 and significance of 0.00

3. $\mathrm{T}$ table obtained at significance $0.05 / 2=0.025$ with degrees of freedom df $=301-2-1$ or 298. Results obtained by 1960

4. Because $t$ count $=7.347>$ tabel $=1.960$, then Ho is rejected, meaning $\mathrm{Ha}$ accepted.

5. Significance Value X1 $=0.00<\alpha=0.05(0.00$ $<0.05)$, means Ho is rejected and Ha accepted where the Product affects the Loyalty of Constituents.

6. Variable Coefficient Tests of "Communication" ( $\beta 2)$

7. T calculated obtained 7,610 and significance of 0.00

8. T table obtained at significance $0.05 / 2=0.025$ with degrees of freedom df $=301-2-1$ or 298. Results obtained by 1960

9. Because thitung $=7.610>$ ttable $=1.960$, then Ho is rejected, it means Ha1 accepted

10. Significance Value X1 $=0.00<\alpha=0.05(0.00$ $<0.05)$, means Ho is rejected and Ha1 accepted where Communications affect the Loyalty of Constituents.

\section{Conclusions}

Based on the results of research and discussion, then in this study can be drawn the following conclusions:

1. Responder of the research variables can be assessed positively shown by the test results of the research instrument has been able to meet the validity validity requirements

2. Whereas the result of the discussion that the Product has an influence on the formation of Constituent Loyalty is $23,7 \%$ and the rest equal to $76.3 \%$ be seen that the change of Constituent Loyalty for each increase of one unit of Product is 0.443 .

3. PDIP must increase its party products to constituents both in quantity and in quality which is expected to increase the formation of constituent loyalty. The influence of the product is still very low on loyalty for it needs to be studied and researched more deeply by PDIP of Central Java about constituent desire to party influenced by other variables From the discussion it can

product whether it is a party policy or regulation, party's personal structural, candidate of legislative, executive candidate and also good partying activities internal or external. Structural consolidation, elections and elections that always have an impact on constituent loyalty, therefore the process should be more attention so as not to have an impact on the decline in constituent loyalty.

4. That the result of discussion of communication variables that the magnitude of the influence of Communication on the formation of Constituent Loyalty is $24,5 \%$ and the rest of $75,53 \%$ influenced by other variables. From the discussion it can be seen that the change of Constituent Loyalty for each increase of one Communication unit is 0.461. That communications built by party structures to constituents are still very low, so that many constituents still do not know what the party does that will have a positive impact on the level of constituent loyalty. Communication plays an important role to increase the party's insight, knowledge and image in society. Communication media and the intensity of party communication to constituents play an important role, both of which are less optimized, thus affecting the level of constituent loyalty.

5. In the test of Regression Coefficient Hypothesis, with the result that Influence of Product and Communication variable to Constituent Loyalty is $36.1 \%$ while the rest $63.9 \%$ is influenced by other variables.

Ethical clearance - Not required

\section{Source of funding- Self}

\section{Conflict of Interest - Nil}

\section{References}

[1] Aaker, J. L., V. Benet-Martinez, and J. Garolera. "Consumption symbols as carriers of culture: A study of Japanese and Spanish brand personality constructs". Journal of Personality and Social Psychology, 81(3), 492-508, (2001).

[2] Adnan Nursal. Political Marketing : Strategi Memenangkan Pemilu. Jakarta: Gramedia Pustaka Utama, 2004.

[3] Afdal Makkuraga Putra. Emosionalitas dan Negativity dalam Iklan Politik Pilkada, Jurnal Media Watch, 31 Agustus 2007.

[4] Ariestonandri, Prima "Marketing Research for Beginner, Panduan Praktis Riset Pemasaran Bagi Pemula" Andi Ofset Yogyakarta, (2006).

[5] Baker, G. "Down at the ranch, barbecuing steers, Bush reveals himself to the world." http//www.timesonline.co.uk (August 12), (2005).

[6] Bauer, H., R. Ma“der, and T. Keller. "An investigation of the brand personality scale. Assessment of validity and implications with regard to brand policy in European cultural domains". Proceedings of the Academy of Marketing Science Multicultural Conference, September 17-20, Kowloon, Hong Kong, (2000).

[7] Beckett, A., "Hi kids, I'm Dave Cameron". Keep it real. http://politics.guardian.- co.uk (January 12), (2006).

[8] Chales H Patti, Edwin Luck and Sherri Chapman. " Building a Brand relationship with voters; The need for IMC within political parties". Queensland University of Technology.

[9] Cravens, David W. \& Nigel F. Piercy, Strategic 
Marketing, Eighth Edition, McGraw-Hill Irwin, Boston, (2006).

[10] Cohen, Jacob, et al. Applied Multiple Regression - Correlation Analysis for the Behavioral Sciences(2002) (ISBN: 0805822232)

[11] Dawes, John (2008), "Do Data Characteristics Change According to the number of scale points used? An experiment using 5-point, 7-point and 10-point scales," International Journal of Market Research, 50 (1), 61-77. $\underline{a}^{\underline{b}}$ Tibshirani, Robert (1996). "Regression Shrinkage and Selection via the Lasso". Journal of the Royal Statistical Society. Series B (Methodological) 58 (1): 267-288

[12] Fajrianthi Zatul Farrah (2005) "Strategi perluasan merek dan loyalitas konsumen” Insan Vol No 3, Desember 2005

[13] Firmanzah. Marketing Politik Antara Pemasaran dan Realitas. Jakarta: Yayasan Obor Fred N. Kerlinger, Elazar J. Pedhazur, Multiple Regression in Behavioral Research. (1973)-- T, 2007.

[14] Freling TH, Forbes LP. An examination of brand personality through methodological triangulation. J Brand Manag 2005;13(2):56-65.

[15] Hikmat Budiman. Iklan Partai Politik dan Konservatisme. Koran Tempo, 27 Maret 2004

[16] Heryanto, 2009, Marketing Politik Melalui Media Massa, 28 Februari 2009 tersedia di http://gunheryanto.blogspot.com/2009/02 (Diakses 07 Maret 2010).

[17] Imawan, Riswandha. "Desentralisasi, Demokratisasi dan Pembentukkan Good Governance" dalam Syamsuddin Haris (editor) et al. Desentralisasi dan Otonomi Daerah: Desentralisasi, Demokratisasi dan Akuntabilitas Pemerintahan Daerah. Jakarta: LIPI Press, 2005.

[18] Ke Xue. "An influence research on brand personality to perceived quality". Internasional journal of bussiness and management, (2007).

[19] Keller, K. L. Branding and brand equity. In B. A. Weitz and R. Wensley (Eds.), Handbook of marketing. London: Sage, (2006).

[20] Klein, J. G. and R. Ahluwalia. "Negativity in the evaluation of political candidates". Journal of Marketing, 69(1), 131-142, (2005).

[21] Kotler, Philip \& Armstrong, Gary, Principles of Marketing, Tenth Edition, Pearson Prentice Hall , New Jersey, 2004.

[22] Kotler, Philip \& Gary Armstrong, "Principles of Marketing" Eleventh Edition, Pearson Prentice Hall, New Jersey, (2006).

[23] Kotler, Philip \& Kevin Lane Keller, "Marketing Management" Twelfth Edition, Pearson, (2006).

[24] Kotler, Philip \& Kevin Lane Keller "Marketing Management" Twelfth Edition, Pearson Kotler, Philip. '2001. Manajemen Pemasaran di indonesia Edisi Bahasa Indonesia. Jakarta: PT. Salemba Empat, (2006)

[25] Keller, Kevin Lane, Strategic Brand Management : Building,Measuring, And Managing Brand Equity, Second Edition, Pearson Prentice Hal , New Jersey, (2003).

[26] Lees-Marshment, "political Marketing" principles and application. Routledge, Aukland University, (2005).

[27] Martinez, Eva \& Jose M. Pina, The Negative Impact of Brand Extensions on Parent Brand Image, Journal of Product \& Brand Management, Vol. 12., No. 7, pp. 432-448, (2003).

[28] Mustofa, Arif (2009) "Analisa Semiotik Pada Iklan Sby Boediono" ( Versi Harian Kompas Periode Mei - Juli 2009) Diposkan oleh.Ikom FS: tofa_sudiro@yahoo.com FB: riefikom.utm@gmail.com

[29] Neil Salkind (Ed.) Encyclopedia of Measurement and Statistics. Thousand Oaks (CA), (2007).

[30] Newman, Bruce I and Perloff, Richard M, Political Marketing : "Theory, Research and Applications, in Kaid, Lynda Lee,

Handbook of Political Communications Research, (London : Lawrence Erlbaum Associates Publisher,), H.24, (2004).

[31] Robbins, Stephen P. Perilaku organisasi. Jakarta : PT. Indeks Kelompok GRAMEDIA, (2003).

[32] Roger, EM \& Storey J.D. “Communication Campaign. In C.R. Berger \& S.H Chaffee; (ed..), Handbook of Communications Science”, (New Burry Park, CA : Sage,), (1987).

[33] Schiffman, L.G., dan L.L. Kanuk. Consumer Behavior. 7th edition. New Jersey:Prentice Hall, (2002).

[34] Sugiono,"Metode Penelitian Bisnis : Pendekatan Kuantitatif, Kualitatif dan R\&D” Alfabeta : Bandung, (2008).

[35] Walgito, Bimo, "Psikologi Sosial (Suatu Pengantar)". Yogakarta. Andi Offset, (2003).

[36] Winarno, Budi. "Teori dan Proses Kebijakan Publik". Med Press. Jakarta, 2002.

[37] Winardi, J. "Manajemen Perilaku Organisasi”. Jakarta : Prenada Media, (2004)

[38] Zethalm and Binner, "Episodic, Extended And Continuous Service Encounters: A Theoretical Framework". Graduate School of Management The University of Queensland, (2006). 